\title{
Antibacterial and antibiotic-modifying activities of fractions and compounds from Albizia adianthifolia against MDR Gram- negative enteric bacteria
}

Cedric F. Tchinda ${ }^{1,2}$, Gaiëlle Sonfack³, Ingrid K. Simo ${ }^{3}$, Illhami Çelik ${ }^{4}$, Igor K. Voukeng ${ }^{1}$, Blaise K. Nganou ${ }^{3}$, Gabin T. M. Bitchagno ${ }^{3}$, Sultan Funda Ekti ${ }^{4}$, Mathieu Tene ${ }^{3}$, Pierre Tane ${ }^{3}$, Veronique P. Beng ${ }^{2}$ and Victor Kuete ${ }^{1 *}$

\begin{abstract}
Background: Albizia adianthifolia (Schum.) is medicinally used in Cameroon to manage bronchitis and skin diseases. Our previous study documented the antibacterial potential of its roots' methanol extract. In this study, methanol roots extract was subjected to chromatography techniques and fractions (AARa and AARb), sub-fractions (AARa1-4, AARb1-2 and AARb11-14) together with isolated phytochemicals were assessed for their antimicrobial as well as their antibiotic-potentiating effects towards Gram-negative multidrug resistant (MDR) bacteria.

Methods: The antibacterial activities of the samples (determination of Minimal Inhibitory « MIC » and Minimal Bactericidal Concentration «MBC ») were determined by the modified rapid p-iodonitrotetrazolium chloride (INT) colorimetric assay, as well as those of antibiotics in association with the compounds. Column chromatography was applied to isolate phytochemicals from roots extract and their chemical structures were determined using spectroscopic techniques.
\end{abstract}

Results: The phytochemicals isolated were stearic acid (1), a mixture (1:1) of stigmasterol and $\beta$-sitosterol $(2+3), \beta$ sitosterol 3-O- $\beta$-D-glucopyranoside (4), palmatin (5), homomangiferin (6) and mangiferin (7). Fraction AARa exhibited selective inhibitory effects whilst all tested bacteria were inhibited by AARb in MIC ranges of 8 to $1024 \mu \mathrm{g} / \mathrm{mL}$. Subfractions AARb1-2 had MIC values between $8 \mu \mathrm{g} / \mathrm{mL}$ and $1024 \mu \mathrm{g} / \mathrm{mL}$ on all tested bacteria. Phytochemicals 4, $2+3$ and 7 inhibited the growth of $54.54 \%(6 / 11), 45.45 \%(5 / 11)$ and $27.27 \%(3 / 11)$ tested bacterial strains, respectively. When tested with an efflux pumps inhibitor (Phenylalanine-Arginine- $\beta$-Naphthylamide or PA $\beta N$ ), the inhibitory effects of compounds $2+3$ and 4 increased towards all the tested bacteria. In association with erythromycin (ERY), streptomycin (STR) and tetracycline (TET), compounds $2+3$ and 4 had the most significant synergistic activity on the seven selected bacteria.

Conclusion: The present study provides information on the possible use of Albizia adianthifolia and its constituents in the control of Gram-negative infections including MDR phenotypes.

Keywords: Albizia adianthifolia, Antibiotic modifying activity, Fabaceae, Multi-drug resistance, Phytochemicals

\footnotetext{
*Correspondence: kuetevictor@yahoo.fr

${ }^{1}$ Department of Biochemistry, Faculty of Science, University of Dschang, P.O.

Box 67, Dschang, Cameroon

Full list of author information is available at the end of the article
}

(c) The Author(s). 2019 Open Access This article is distributed under the terms of the Creative Commons Attribution 4.0 International License (http://creativecommons.org/licenses/by/4.0/) which permits unrestricted use, distribution, and reproduction in any medium, provided you give appropriate credit to the original author(s) and the source, provide a link to the Creative Commons license, and indicate if changes were made. The Creative Commons Public Domain Dedication waiver (http://creativecommons.org/publicdomain/zero/1.0/) applies to the data made available in this article, unless otherwise stated. 


\section{Background}

Bacteria infectious still constitute a serious health concern worldwide and is responsible for the high morbidity and mortality. In spite of the progress achieved by pharmaceutical industries in the synthesis of new antibacterial agents in recent years, the resistance to available drugs remains a major problem globally [1]. Besides, the continuous emergence of multi-resistant bacteria considerably reduces the efficiency of antibiotics, increases the frequency of therapeutic failures and incurs economic burden, all of this in association with undesired side effects of synthetic antibiotics makes the fight against bacterial infection complicated $[2,3]$. The resistance of these bacteria to the antimicrobial agents can be associated to the presence of membrane transporting systems called efflux pumps that would be responsible for the over expression of the multi-resistance phenomenon [4]. It is worth noting that among Gram-negative bacteria, the effect of the combination of efflux pumps and the reduction of membrane permeability is responsible for the high resistance against antibiotics often associated to these groups of organisms [5]. Among the Gram-negative bacteria, those presenting multi-resistance phenotype belong mostly to the RND (Resistance Nodulation-Cell division) family which is a tripartite efflux pump. The increasing multi-drug resistance (MDR) and the lack of novel antibiotics propel the research of new antibacterial agents from medicinal plants. This is especially prominent as plants and their derived substances have long been used by humans for medicinal purposes [6]. Today, it is estimated that about $80 \%$ of the world's population have integrated the use of medicinal plant as primary healthcare modality [7]. Recently, several bioactive compounds have been reported to fight against MDR bacteria [8]. Some examples include Paullinia pinnata $[9,10]$, Combretum mole [11] and Harungana madagascariensis [12]. In our continuous endeavors to identify antibacterial agents from plants traditionally used to fight microbial infection targeted Albizia adianthifolia (Schum.) (Fabaceae). The plant is used in traditional medecine to treat skin diseases, bronchitis, inflamed eyes, tapeworm, headaches and sinusitis $[13,14]$. In earlier studies on this plant, adianthifoliosides A, B and D [15, 16], lupeol, aurantiamide acetate [17] and prosapogenins [18] were isolated. Previously, we demonstrated the antibacterial activity of the methanol extract from the roots (AAR) [19]. Herein, a bioassay guided fractionation was conducted for in-depth analysis of the antibacterial as well as antibiotic-modulating effect of the methanol extract from the roots of Albizia adianthifolia.

\section{Methods}

\section{General procedure}

The spectrometers were used to register the high resolution mass spectra (HRMS) (Shimadzu hybrid LC-MS-
IT-TOF) and NMR Spectra (Agilent DD2 NMR (400 $\mathrm{MHz})$ spectrometer). The silica gel Merck $60 \mathrm{~F}_{254}[(0.2-$ $0.5 \mathrm{~mm})$ and $(0.2-0.063 \mathrm{~mm})]$ 70,230 and 230-400 mesh (Darmstadt, Germany) was used in column chromatography $(\mathrm{CC})$ while pre-coated silica gel $60 \mathrm{~F}_{254}$ was used to analyze on thin layer chromatography (TLC) plates (Merck, Germany). The TLC was revealed with 20\% sulphuric acid $\left(\mathrm{H}_{2} \mathrm{SO}_{4}\right)$, heated at $100{ }^{\circ} \mathrm{C}$.

\section{Plant material and extraction}

The roots of Albizia adianthifolia were harvested in Mont Kala, Center Region (Cameroon) on April 2015. The botanical identification was confirmed by Dr. Marie Florence Sandrine Ngo Ngwe at the National herbarium of Cameroon (Yaoundé) by comparison with the voucher specimen available under the reference number 24729/ SRF/Cam (roots, leaves, bark). No permission was necessary for sample's collection. The powdered roots of $A$. adianthifolia $(3000 \mathrm{~g})$ were soaked in methanol $(\mathrm{MeOH}$; $8 \mathrm{~L}$ ) for $48 \mathrm{~h}$. After filtration and removal of the solvent using a rotary evaporator under reduced pressure, $124 \mathrm{~g}$ of crude extract (AAR) was obtained.

\section{Isolation and purification of bioactive compounds from the roots extract of $A$. adianthifolia}

A portion of AAR $(122.50 \mathrm{~g})$ was dissolved in water (100\%), followed by liquid-liquid exhaustion in ethyl acetate (AcOEt). Two new fractions named AARa (36.50 g, EtOAc) and a AARb (82.5 g; residual portion) were obtained. Fraction AARb fraction (82.5 g) was further dissolved in water (100\%), followed by liquid-liquid exhaustion in n-butanol (n-BuOH) to afford two subfractions named AARb1 (49.3 g; n-BuOH) and AARb2 a residual fraction (28.5 g).

Part of the fraction AARa (33.50 g) was subjected to silica gel column chromatography $(\mathrm{CC})$ eluting with gradient of Hexane-EtOAc then EtOAc-MeOH. Sixty-one fractions of $300 \mathrm{~mL}$ each were collected and combined on the basis of their thin layer chromatography (TLC) profiles into four main fractions (frs) coded AARa1-4 [AARa1 (1-12, 4.80 g), AARa2 (13-30, 4.60 g), AARa3 (31-39, 4 g) and AARa4 (40-61, $8 \mathrm{~g})]$. Fraction AARa1 was filtered and washed with EtOAc to yield compound $\mathbf{1}$ as white powder $(20 \mathrm{mg})$. Fraction AARa2 was filtered and washed with EtOAc to yield a mixture of phytosterols 2 and 3 (50 mg) as white powder. Fraction AARa4 $(8 \mathrm{~g})$ was subjected to silica gel CC eluting with a gradient of EtOAc-MeOH (100:0, 97: 3, 94: 6, 91: 9, 85: 15, 0: 100) affording six new sub-fractions (sub-frs) (AARa41AARa46). Sub-fraction AARa41 was filtered and washed with ethyl acetate to yield compound $4(25 \mathrm{mg})$ as a white powder. Sub-fractions AARa43 was further subjected to Sephadex LH-20 eluted with $\mathrm{MeOH}$ to yield compound $\mathbf{5}$ as a yellow powder $(30 \mathrm{mg})$. 
Part of the sub-fraction AARb1 (47 g) was subjected to silica gel CC eluting with gradient of EtOAc-MeOH. Ninety-two fractions of $300 \mathrm{~mL}$ each were collected and combined based on their TLC profiles into four main fractions coded AARb1-4 [AARb1 (1-12; $5.40 \mathrm{~g})$, AARb2 (13-34; $8.50 \mathrm{~g})$, AARb3 (35-76; $14.50 \mathrm{~g})$ and AARb4 (77-92; $12.70 \mathrm{~g})$ ]. Fraction AARb3 (13 g) was subjected to silica gel column chromatography eluting with a gradient of EtOAc-MeOH (100: 0, 95: 5, 90: 10, 85: 15, 80: 20, 70: 30, 0: 100) affording five sub-fractions AARb31- AARb35. Sub-fraction AARb32 was further subjected to Sephadex LH-20 eluted with $\mathrm{MeOH}$ to yield compound $6(20 \mathrm{mg})$ and compound $7(25 \mathrm{mg})$ as yellow powder each. This procedure of purification was bioguided by antibacterial activity.

\section{Antibacterial assays}

\section{Chemicals for antibacterial assays}

In this study, reference antibiotics used included: chloramphenicol (CHL), ciproflocaxin (CIP), erythromycin (ERY), gentamycin (GEN), kanamycin (KAN), norflocaxin (NOR), penicillin G (PEN), streptomycin (STR), and tetracycline (TET) obtained from Sigma-Aldrich (St Quentin Fallavier, France). Dimethyl sulfoxide (DMSO, Sigma-Aldrich) was used to dissolve the tesyed samples. The microbial growth indicator used was $p$-iodonitrotretrazolium chloride $\geq 97 \%$ (INT, Sigma-Aldrich) while the Efflux Pump Inhibitor (EPI) used was phenylalaninearginine- $\beta$-naphthylamide (PA $\beta N)$.

\section{Bacterial strains and culture media}

A panel of 15 Gram-negative bacteria were investigated in this work. They included resistant strains of Escherichia coli, Enterobacter aerogenes, Klebsiella pneumoniae, Providencia stuartii and Pseudomonas aeruginosa. The bacteria strains used in this study were obtained both from the American Type Culture Collection (ATCC) or were clinical Laboratory isolates. Their bacterial characteristics were earlier given (Additional file 1; Table S1) [10]. Prior to the test, bacteria were cultured on Mueller Hinton Agar (MHA; Sigma) slant meanwhile Mueller Hinton Broth (MHB; Sigma) was used for antibacterial assay [20].

\section{Antibacterial testing}

The minimum inhibitory concentration (MIC) of samples was evaluated following the broth microdilution using the well-known rapid INT method [21, 22]. Fractions, compounds and reference drug were dissolved in DMSO-MHB. The bacterial inoculum used was $1.5 \times$ $10^{6} \mathrm{CFU} / \mathrm{mL}$ and the incubation conditions at $37^{\circ} \mathrm{C}$ and $18 \mathrm{~h}$. DMSO at less than $2.5 \%$ was used as solvent control while CHL was used as positive control.
Six isolated compounds were tested in the presence of an efflux inhibitor (EPI), PA $\beta \mathrm{N}$ (at $30 \mu \mathrm{g} / \mathrm{mL}$ ) against ten bacteria including resistant strains in order to evaluate the role of efflux pumps in their resistance ability.

A preliminary assay was performed by assessing a combination of isolated phytochemical $(2+3)$ at its various sub-inhibitory concentration and antibiotic on PA124 (see Additional file1; Table S3) which permitted us selecting appropriate sub-inhibitory concentration for further potentiating effect on other bacteria. Therefore, $\mathrm{MIC} / 2$ and MIC/4 were subsequently used for sampleantibiotics combination on more bacteria $[6,9,23,24]$.

Fractional inhibitory concentrations were calculated as the ratio of MIC of antibiotic in the combination, to that of the antibiotic alone $\left(\mathrm{MIC}_{\text {Antibiotic in combination }} / \mathrm{MIC}_{\mathrm{An}-}\right.$ tibiotic alone) and the interpretation done thus; Synergistic $(\leq 0.5)$, Indifferent (1 to 4$)$, or antagonistic $(>4)[25,26]$.

\section{Results}

\section{Phytochemicals}

The chemical structures of compounds (Fig. 1) namely stearic acid $\mathrm{C}_{18} \mathrm{H}_{36} \mathrm{O}_{2}\left(1, m / z\right.$ 284, m.p.: $\left.68-70{ }^{\circ} \mathrm{C}\right)$ [27], mixture (1:1) of stigmasterol and $\beta$-sistosterol $(2+3)$ [28], $\beta$-sitosterol 3-O- $\beta$ - $_{\mathrm{D}}$-glucopyranoside $\mathrm{C}_{35} \mathrm{H}_{60} \mathrm{O}_{6}(4$, $m / z$ 576) [29], palmatin $\mathrm{C}_{21} \mathrm{H}_{22} \mathrm{NO}_{4}{ }^{+}(5, \mathrm{~m} / z$ 352, m.p.: 204-206 $\left.{ }^{\circ} \mathrm{C}\right)$ [30], homomangiferin $\mathrm{C}_{20} \mathrm{H}_{20} \mathrm{O}_{11}(6, \mathrm{~m} / z$ 436, m.p.: $\left.249-251^{\circ} \mathrm{C}\right)$ [31] and mangiferin $\mathrm{C}_{19} \mathrm{H}_{18} \mathrm{O}_{11}$ (7, $m / z$ 422, m.p.: $\left.259-260^{\circ} \mathrm{C}\right)$ [32], from $A$. adianthifolia roots extract, were determined using physical and NMR $\left({ }^{1} \mathrm{H},{ }^{13} \mathrm{C}\right.$ and $\left.2 \mathrm{D}\right)$ data, in comparison with those of related compounds in the literature (Additional file 1)

\section{Antibacterial activity}

The inhibitory potential towards 15 Gram-negative bacteria of fractions (AARa-b), sub-fractions fractions (AARa1-4, AARb1-2 and AARb11-14) as well as phytochemicals from the roots of $A$. adianthifolia, and CHL is given in Tables 1 and 2. It appears from data in Table 1 that the tested botanicals (crude extract, fractions and sub-frs) and phytochemicals were selectively active. The recorded MIC values were in the range of 8 to $1024 \mu \mathrm{g} /$ $\mathrm{mL}$. However, fraction AARb was active on 15 of the 15 (100\%) bacteria tested, while AARa was active on $73.33 \%$ $(11 / 15)$ of them. MICs $\leq 256 \mu \mathrm{g} / \mathrm{mL}$ were obtained with CHL on $100 \%(15 / 15)$ of the bacteria tested. MBC $\leq$ $1024 \mu \mathrm{g} / \mathrm{mL}$ were noted with AARa-b on some of the studied bacteria. Table 1 shows the MICs and MBCs of AARa sub-frs (AARa1-4) on the panel of 15 bacteria. As a result, the AARa2 and AARa3 sub-frs had MICs ranged from 16 and $1024 \mu \mathrm{g} / \mathrm{mL}$ on all tested pathogens contrary to other sub-frs showed selective activities. These inhibitory activities were observed on $68.66 \%$ (13/ 15), $80 \%(12 / 15), 40 \%(6 / 15)$ and $33.33 \%(5 / 15)$ bacteria 
<smiles>CCC(C)(C)CC(C)(C)CC(=O)O</smiles><smiles>CCC(CCC(C)C1CCC2C3CC=C4CC(OC5OCC(O)C(O)C(O)C5O)CCC4(C)C3CCC12C)C(C)C</smiles><smiles></smiles>
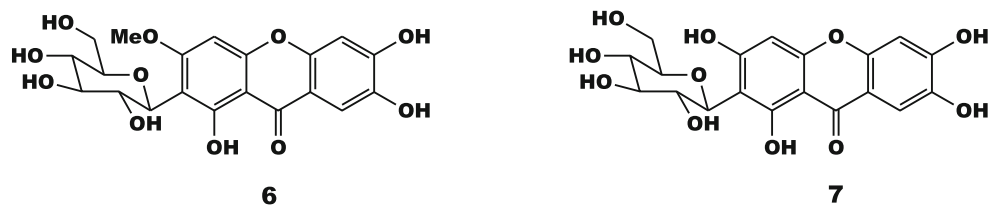

Fig. 1 Chemical structures of compounds isolated from the roots of Albizia adianthifolia. Stearic acid (1), mixture of stigmasterol and $\beta$-sitosterol $(\mathbf{2}+\mathbf{3})$, $\beta$-sitosterol 3-O- $\beta$-o-glucopyranoside (4), palmatin (5), homomangiferin (6) and mangiferin (7)

tested with the sub-fractions AARa2, AARa3, AARa4 and AARa1 respectively. MICs and MBCs as seen in Table 1 for AARb sub-fractions (AARb1-2) on the panel of 15 bacteria indicated that AARb1-2 had MICs ranged from 8 to $1024 \mu \mathrm{g} / \mathrm{mL}$ on all the tested bacteria. They were active on $93.33 \%(14 / 15)$ of the tested bacteria. The investigation of sub-fractions of AARb11-AARb14 is summarized in Table 1 as well. MICs varying from 8 to $1024 \mu \mathrm{g} / \mathrm{mL}$ were obtained and the recorded inhibitory effects were noted on $100 \%$ (15/15), 93.33\% (14/15), 80\% $(12 / 15)$ and $60 \%(9 / 15)$ of the bacteria tested with AARb13, AARb14, AARb11 and AARb12 respectively. In general, the MBCs were above $1024 \mu \mathrm{g} / \mathrm{mL}$.

The antibacterial activity of compounds isolated from the roots of $A$. adianthifolia is compiled in Table 2. Compounds $4,2+3$ and 7 respectively inhibited the growth of $54.5 \%(6 / 11), 45.4 \%(5 / 11)$ and $27.3 \%(3 / 11)$ of tested bacteria, whereas compounds 5 and $\mathbf{6}$ exhibited similar activities by inhibiting each $36.7 \%(4 / 11)$ bacteria tested. The activity of the compound $(2+3)$ vis-à-vis $K$. pneumoniae KP55 (MIC of $32 \mu \mathrm{g} / \mathrm{mL}$ ); compounds $\mathbf{2}+\mathbf{3}$ and 4 vis-a-vis $P$. aeruginosa PA01 (MIC of $16 \mu \mathrm{g} / \mathrm{mL}$ and MIC of $2 \mu \mathrm{g} / \mathrm{mL}$ respectively) and compound 4 vis-àvis $P$. aeruginosa PA124 (MIC of $128 \mu \mathrm{g} / \mathrm{mL}$ ) were greater compared to that of CHL. At a concentration as high as $128 \mu \mathrm{g} / \mathrm{mL}$, compound $\mathbf{1}$ had no antibacterial activity. The bactericidal effect of $2+3,4$ and
5 were noted vis-à-vis $3 / 11,2 / 11$ and $1 / 11$ pathogens tested respectively.

Influence of the bacterial efflux pumps on the activity of the tested phytochemicals

Ten selected MDR bacteria were tested in the presence of EPI $(\mathrm{PA} \beta \mathrm{N})$. It appears that in the combination with $\mathrm{PA} \beta \mathrm{N}$, the activities of compounds $\mathbf{2}+\mathbf{3}$ and $\mathbf{4}$ were ameliorated against $100 \%(10 / 10)$ of tested MDR strains (Table 3) while the other compounds (5, 6 and 7) displayed moderate activity in the presence of EPI.

\section{Potentiating effect of phytochemicals}

Based on results obtained from a preliminary study carried out on Pseudomonas aeruginosa PA124, three isolated molecules were associated with seven antibiotics (CIP, ERY, GEN, KAN, NOR, STR, and TET) to ascertain the ability to potentiate their activities. Tables 4 and 5 show synergies between phytochemicals and the majority of antibiotics. These synergistic effects varied from 28.57 to $100 \%$ on the various microorganisms with all the compounds. In combination with ERY and STR antibiotics, all compounds $\mathbf{2}+\mathbf{3}$ and $\mathbf{4}$ showed the most significant synergistic effects $(100 \%)$ at their different subinhibitory concentrations ( $\mathrm{MIC} / 2$ and $\mathrm{MIC} / 4)$. Besides, these samples, namely compounds $\mathbf{2}+\mathbf{3}$ and $\mathbf{4}$ in association with KAN, presented the weakest synergistic effects, ranging from 28.57 to $71.42 \%$ compared to the 


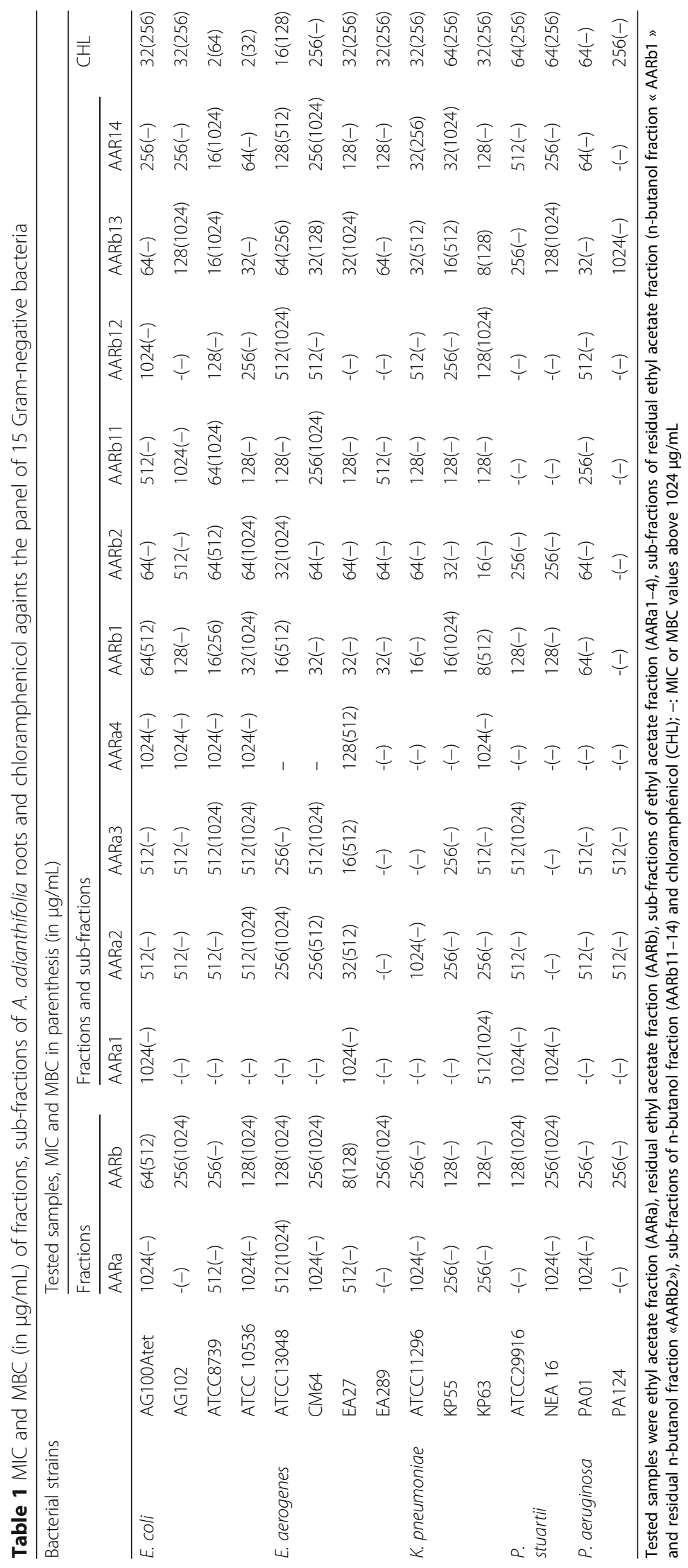


Table $2 \mathrm{MIC}$ and MBC (in $\mu \mathrm{g} / \mathrm{mL}$ ) of compounds isolated from A. adianthifolia roots againts the panel of 11 Gram-negative bacteria

\begin{tabular}{|c|c|c|c|c|c|c|}
\hline \multirow{2}{*}{$\begin{array}{l}\text { Bacterial } \\
\text { strains }\end{array}$} & \multicolumn{6}{|c|}{ Compounds, MIC and MBC in parenthesis (in $\mu \mathrm{g} / \mathrm{mL}$ ) } \\
\hline & $2+3$ & 4 & 5 & 6 & 7 & $\mathrm{CHL}$ \\
\hline \multicolumn{7}{|l|}{ E. coli } \\
\hline AG102 & - & $128(-)$ & - & - & - & $32(-)$ \\
\hline ATCC8739 & - & $16(32)$ & - & - & - & $2(64)$ \\
\hline ATCC 10536 & $16(32)$ & $16(32)$ & - & $32(-)$ & $64(-)$ & $2(32)$ \\
\hline \multicolumn{7}{|l|}{ E. aerogenes } \\
\hline ATCC13048 & $128(-)$ & $128(-)$ & $128(-)$ & $128(-)$ & $128(-)$ & $16(-)$ \\
\hline $\mathrm{EA} 27$ & - & - & - & - & - & $32(-)$ \\
\hline \multicolumn{7}{|l|}{ K. pneumoniae } \\
\hline ATCC11296 & - & - & $128(-)$ & - & - & $32(-)$ \\
\hline KP55 & $32(64)$ & - & $128(-)$ & $128(-)$ & $128(-)$ & $64(-)$ \\
\hline P. stuartii & & & & & - & \\
\hline ATCC29916 & $64(128)$ & - & $64(128)$ & $128(-)$ & - & $64(-)$ \\
\hline NEA 16 & - & - & - & - & - & $64(-)$ \\
\hline \multicolumn{7}{|l|}{ P. aeruginosa } \\
\hline PA01 & $16(64)$ & $2(64)$ & - & - & - & $64(-)$ \\
\hline PA124 & - & $128(-)$ & - & - & - & - \\
\hline
\end{tabular}

-: MIC or MBC values above $128 \mu \mathrm{g} / \mathrm{mL}$; compound 1 was not active at up to $128 \mu \mathrm{g} / \mathrm{mL}$

other antibiotics of the panel used. The synergistic effect was also noted (100\%) with compounds $2+3$ and $\mathbf{4}$ in combination with TET against the tested bacteria (Table 4); this was also the case when compound $\mathbf{4}$ (at $\mathrm{MIC} / 2$ ) was combined with GEN (Table 5). No antagonistic effect was noted when compounds were combined with antibiotics. However, indifference effects were observed in some cases.

\section{Discussion}

\section{Phytochemicals}

Several compounds (seven compounds) were identified in the present work, this include; fatty acid (1), mixture of steroids $(2+3)$, one steroid glycoside $(4)$, one alkaloid (5), and two xanthones $(6,7)$. The isolation of compounds such as adianthifoliosides (A, B and D), lupeol, aurantiamide acetate, prosapogenins from Albizia adianthifolia was published earlier [15-18]. Nonetheless, few phytochemicals were isolated herein. This could likely be because all fractions were not explored as the isolation procedure was biologically guided.

\section{Antibacterial effects}

The need to search for new effective phytochemicals to combat MDR bacteria is timely. Thus, the activities of plant samples could be attributable to the presence of their phytochemical constituents [33, 34]. Previously we documented the antibacterial effects of crude extracts of Albizia adianthifolia leaves, bark and roots extracts [19]. This was the rationale for performing, in the present work, the bioguided purification of the roots extract. The inhibitory effect of the root extract of Albizia adianthifolia (AAR) was moderate [35], with MICs $\leq 625 \mu \mathrm{g} / \mathrm{mL}$ against various Gram-negative bacteria [19]. In the present study, fractionation of AAR afforded more effective fractions and sub-frs (Table 1 ). The recorded MIC values highlight the good activities of AARb vis-à-vis E. coli AG100Atet $(64 \mu \mathrm{g} / \mathrm{mL})$ and E. aerogenes EA27 $(8 \mu \mathrm{g} / \mathrm{mL})$, AARa2 and AARa3 against $E$. aerogenes EA27 $(32 \mu \mathrm{g} / \mathrm{mL}$ and $16 \mu \mathrm{g} / \mathrm{mL}$ respectively), AARb1 and AARb2 against $K$. pneumoniae KP63 $(8 \mu \mathrm{g} / \mathrm{mL}$ and $16 \mu \mathrm{g} / \mathrm{mL}$ respectively), AARb14 and AARb11 against $E$. coli ATCC8739 $(16 \mu \mathrm{g} / \mathrm{mL}$ and $64 \mu \mathrm{g} / \mathrm{mL}$ respectively) and AARb13 against $K$. pneumoniae KP63 $(8 \mu \mathrm{g} / \mathrm{mL})$.

Table $3 \mathrm{MIC}$ in $\mu \mathrm{g} / \mathrm{mL}$ of compounds and chloramphenicol in the presence of PABN

\begin{tabular}{|c|c|c|c|c|c|c|c|c|c|c|c|c|c|c|c|c|c|c|c|}
\hline \multirow[t]{3}{*}{ Bacterial strains } & & \multicolumn{18}{|c|}{ Tested samples, MIC alone, MIC in the present of PAßN $(\mu \mathrm{g} / \mathrm{mL})$, and ameliorating factor (FA) } \\
\hline & & \multicolumn{3}{|c|}{$2+3$} & \multicolumn{3}{|l|}{4} & \multicolumn{3}{|l|}{5} & \multicolumn{3}{|l|}{6} & \multicolumn{3}{|l|}{7} & \multicolumn{3}{|l|}{$\mathrm{CHL}$} \\
\hline & & MIC & $+P A \beta N$ & FA & $\mathrm{MIC}$ & $+P A \beta N$ & FA & $\mathrm{MIC}$ & $+\mathrm{PA} \beta \mathrm{N}$ & FA & $\mathrm{MIC}$ & $+P A \beta N$ & FA & MIC & $+\mathrm{PA} \beta \mathrm{N}$ & FA & MIC & $+P A \beta N$ & FA \\
\hline \multirow[t]{2}{*}{ E. coli } & AG102 & - & 128 & $>1$ & 128 & 64 & 2 & - & - & - & - & - & - & - & - & - & 32 & 4 & 8 \\
\hline & ATCC10536 & 16 & 4 & 4 & 16 & 8 & 2 & - & 128 & $>1$ & 32 & 8 & 4 & 64 & 8 & 8 & 2 & $<1$ & $<2$ \\
\hline \multirow[t]{2}{*}{ E. aerogenes } & ATCC13048 & 128 & 64 & 2 & 128 & 32 & 4 & 128 & 64 & 2 & 128 & 64 & 2 & 128 & 32 & 4 & 16 & 8 & 2 \\
\hline & EA27 & - & 128 & $>1$ & - & 128 & $>1$ & - & - & - & - & - & - & - & - & - & 32 & 16 & 2 \\
\hline \multirow[t]{2}{*}{ K. pneumoniae } & ATCC11296 & - & 128 & $>1$ & - & 128 & $>1$ & 128 & 32 & 4 & - & - & - & - & - & - & 32 & 8 & 4 \\
\hline & KP55 & 32 & 8 & 4 & - & 128 & $>1$ & 128 & 64 & 2 & 128 & 128 & 1 & 128 & 16 & 8 & 64 & 32 & 2 \\
\hline \multirow[t]{2}{*}{ P. stuartii } & ATCC29916 & 64 & 2 & 32 & - & 16 & $>8$ & 64 & 16 & 4 & 128 & 32 & 4 & - & - & - & 64 & 8 & 8 \\
\hline & NEA16 & - & 8 & $>16$ & - & 16 & $>8$ & - & 128 & $>1$ & - & 128 & $>1$ & - & 128 & $>1$ & 64 & 16 & 4 \\
\hline \multirow[t]{2}{*}{ P. aeruginosa } & PA01 & 16 & 8 & 2 & 2 & $<1$ & $>2$ & - & - & - & - & - & - & - & - & - & 64 & 8 & 8 \\
\hline & PA124 & - & 2 & $>64$ & 128 & 64 & 2 & - & 128 & $>1$ & - & - & - & - & - & - & 256 & 16 & 16 \\
\hline
\end{tabular}

CHL chloramphenicol, PAßN Phenylalanine arginyl ß-Naphtylamide. Ameliorating factor: correspond to the ratio MIC of sample tested alone/ MIC of sample in presence of PAßN, -: > $1024 \mu \mathrm{g} / \mathrm{mL}$ (case of crude extract), $-:>128 \mu \mathrm{g} / \mathrm{mL}$ (case of compounds). PAßN was tested at $30 \mu \mathrm{g} / \mathrm{mL}$ 


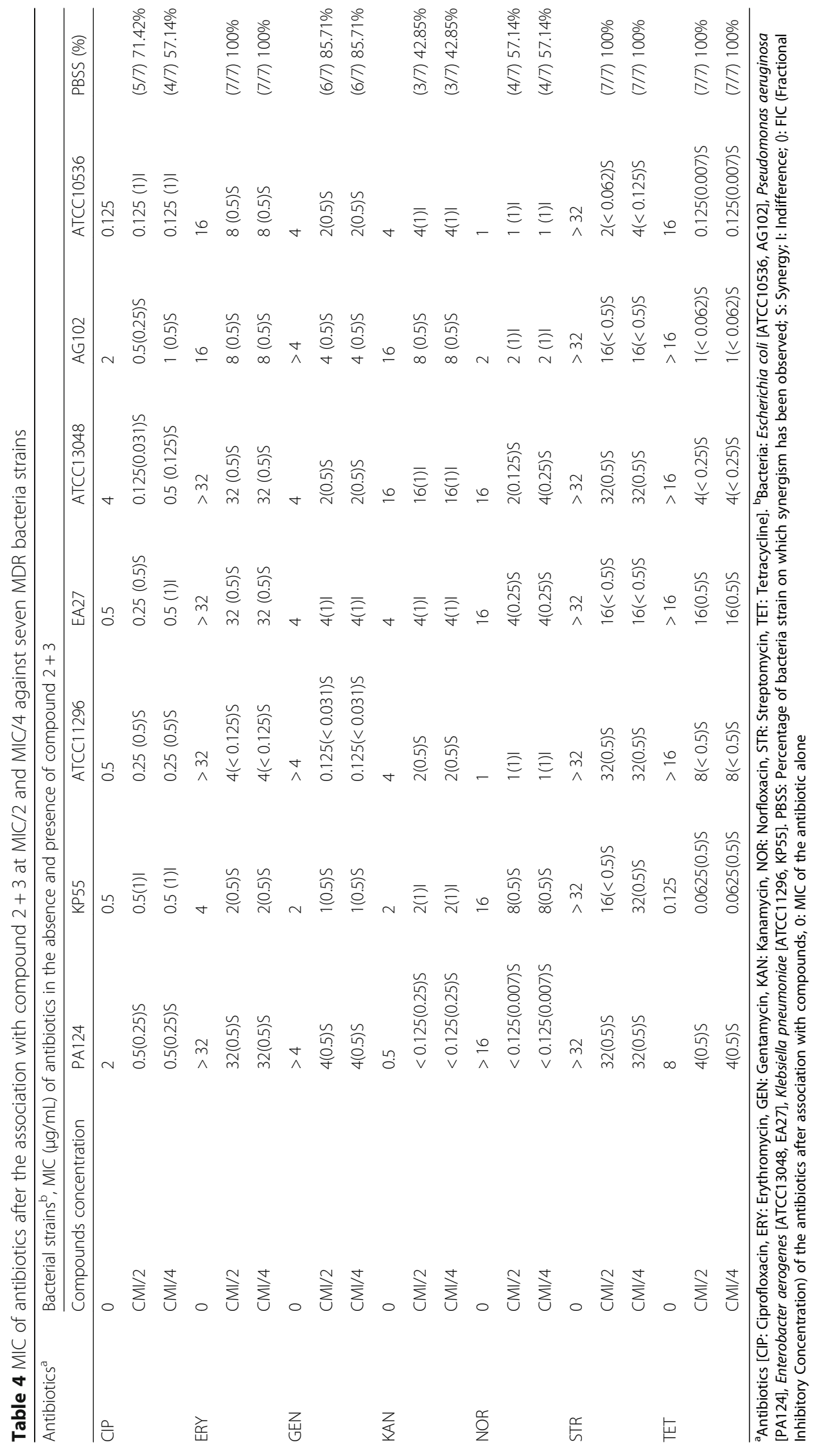




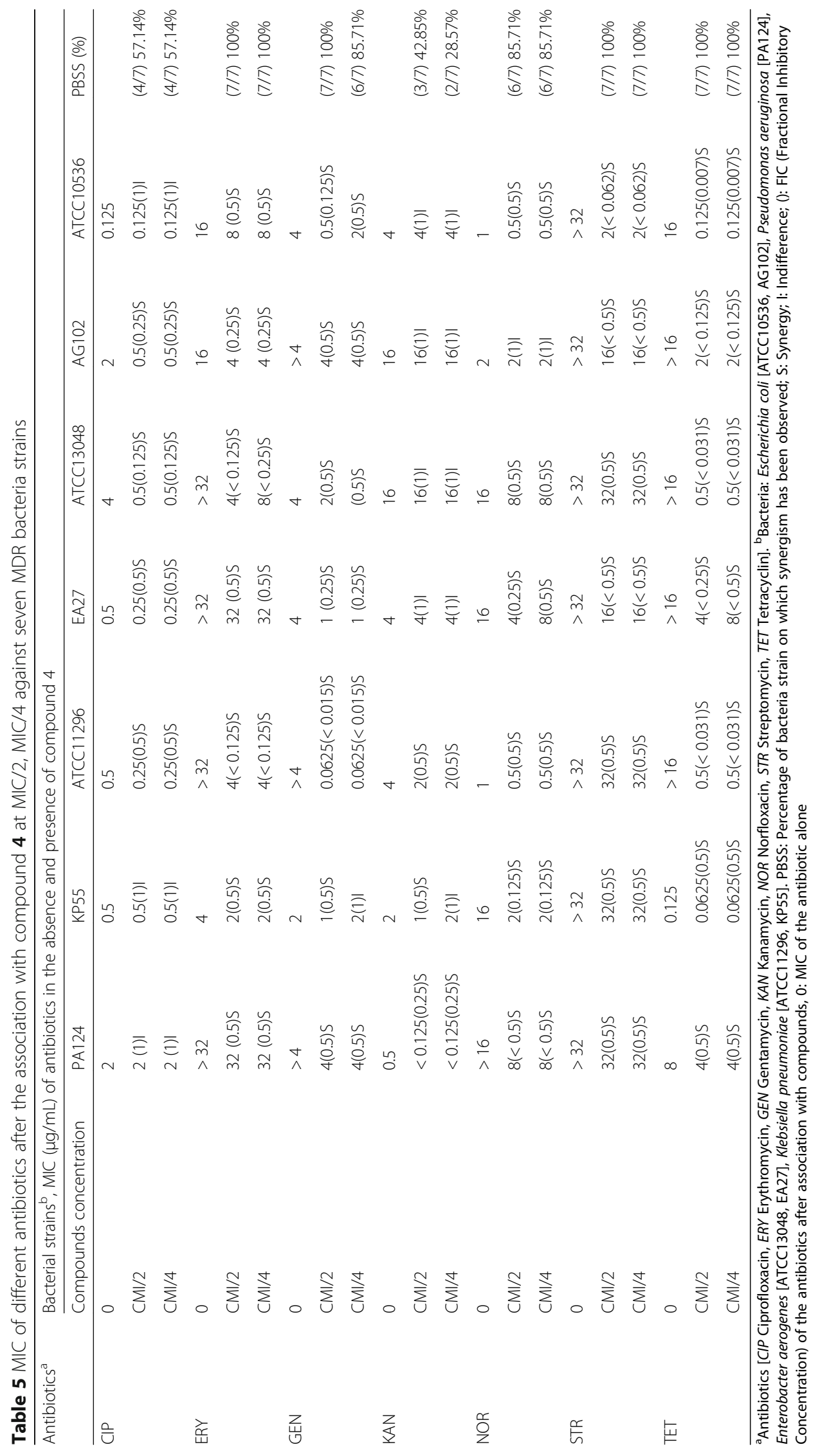


This clearly demonstrates the increase in the activity related to the subsequent fractionation of the plant extract, thus reflecting the good antibacterial potential of Albizia adanthifolia. It should also be noted that AARb1 and AARb2 showed MICs $<100 \mu \mathrm{g} / \mathrm{mL}$ on the majority of bacteria (11/15) (Table 1). The MBC/MIC ratios obtained were generally greater than 4 , highlighting the bacteriostatic effects of extracts studied as well as the active fractions [36, 37]. According to established cutoff points [38], the antibacterial activity of phytochemicals are significant when MICs $<10 \mu \mathrm{g} / \mathrm{mL}$, moderate when MICs are between 10 and $100 \mu \mathrm{g} / \mathrm{mL}$, and low if the MICs $>100 \mu \mathrm{g} / \mathrm{mL}$. On the basis of this scale, compound 4 had significant antibacterial effects against $P$. aeruginosa PA01 (MIC of $2 \mu \mathrm{g} / \mathrm{mL}$ ) strain. Overall MIC data obtained with the compounds were much higher than those of the most active sub-fractions from where they were isolated (AARb1-2 and AARb13). This suggests that the antibacterial activity of its sub-fractions could be due to the synergistic effects of its different constituents. This is also an indication that the fight against the pathogens tested with fractions, sub-fractions and mainly AARb13 (sub-fraction) could be more effective than with isolated compounds.

\section{Role of efflux pumps in the susceptibility of gram- negative bacteria to the tested samples}

The efflux systems involved in this mechanism are tripartite complexes, including the AcrAB-TolC and MexAB-oprM pumps of Enterobacteriaceae and P. aeruginosa respectively $[39,40]$, which play a central role in the multidrug resistance of Gram-negative bacteria. The restoration of the sensitivity of bacteria by the use of efflux pumps inhibitors (IPE) to allow an achievement of the antibacterial threshold concentration, capable of inducing the death of the bacterial cell is the best-known way to combat this type of resistance. PAßN is a potent inhibitor of the aforementioned pumps [41]. In this study, it was found that compounds $2+3$ and 4 showed an improvement in their activity in the presence of EPI on $100 \%$ of the pathogens used. These phytochemicals in combination with EPI could be used in the fight against bacterial infections due to multidrug-resistant phenotypes over-expressing active efflux pumps. The other compounds, namely, 5, 6 and 7 , which had a rather moderate improvement both in intensity and frequency, would be least affected by the effect of efflux pumps. The improvement of the activity of these substances (compounds) in the presence of PA $\beta N$ could also be explained by a facilitation of the penetration of the active principles into the bacterial cells as previously demonstrated by Lamers et al. [42] with $P$. aeruginosa.
Effects of association of compounds with antibiotics Synergistic effects following the combination of the compounds $(2+3$ and 4$)$ with ERY, STR, as well as with GEN and compounds $\mathbf{2}+\mathbf{3}$ and $\mathbf{4}$ with TET with respect to all the bacteria tested were noted. Synergistic or modulatory effects of the compounds $(2+3$ and 4$)$ with other antibiotics were found on more than $70 \%$ of bacteria tested in several cases, with FIC values, ranging mostly from 0.5 to 0.007 . These results suggest that those compounds could be considered as a potential efflux inhibitor [23]. The antibacterial potential of compounds $(2+3$ and 4$)$ in the inhibition of resistant Gramnegative bacteria is reported here for the first time, as well as their antibiotic-modulatory effects. This study also provides more information on the antibacterial activity of compounds $(2+3$ and $\mathbf{4})$ against MDR bacteria.

\section{Conclusion}

Data reported in the present investigation suggest that bioactives from root of Albizia adianthifolia are potential sources of antibacterials to tackle resistant phenotypes. To overcome bacterial resistance, compounds $2+$ 3 and $\mathbf{4}$ could also possibly be used in association with antibiotics.

\section{Additional file}

Additional file 1: Table S1. Bacterial strains used and their features. S2 ${ }^{1} \mathrm{H}, 13 \mathrm{C}$ RMN and major chemical shifts of studied compounds. Table S3 Preliminary evaluation of antibiotic-resistance modulatory activity of selected samples at sub-inhibitory concentrations against Pseudomonnas aeruginosa PA124. (DOC $848 \mathrm{~kb}$ )

\section{Abbreviations}

AAR: Methanol extract from the roots of Albizia adianthifolia; AARab: fractions from AAR; ATB: Antibiotic; ATCC: American Type Culture Collection; CC: Column chromatography; CFU: Colony Forming Unit; CHL: Chloramphenicol; CIP: Ciprofloxacin; DMSO: Dimethyl sulfoxide; $E$. aerogenes: Enterobacter aerogenes; E. coli: Escherichia coli; ERY: Erythromycin; EtOAc: Ethyl acetate; GEN: Gentamycin; INT: p-iodonitrotetrazolium chloride 297\% (INT, Sigma-Aldrich); K. pneumoniae: Klebsiella pneumoniae; KAN: Kanamycin; MBC: Minimal Bactericidal Concentration; MDR: Multidrug resistant; MeOH: Methanol; MHB: Mueller Hinton Broth; MIC: Minimal Inhibitory Concentration; NOR: Norflocaxin; P. aeruginosa: Pseudomonas aeruginosa; P. stuartii: Providencia stuartii; PEN: Penicillin; STR: Streptomycin; TET: Tetracyclin; TLC: Thin Layer Chromatography; AARb1-2: Sub-fractions from AARb; AARa1-4: Sub-fractions from AARa

\section{Acknowledgements}

Authors are thankful to the Cameroon National Herbarium (Yaounde) for the plant identification. The authors also acknowledge the Anadolu University for its technical assistance in NMR analysis.

\section{Authors' contributions}

CFT, GS and IKV carried out the study; CFT and VK wrote the manuscript; IKS and $V K$ designed the experiments; IC and SFE registered the chemical spectra; IKS, BKN and GTMB contributed to structural elucidation; VK, MT, PT and VPB supervised the work; VK provided the bacterial strains and facilities for antibacterial assays; all authors read and approved the final manuscript. 


\section{Funding}

This study was partially funded by the Scientific Research Projects Commission of Anadolu University, Eskisehir, Turkey (1306F110).

\section{Availability of data and materials}

All data generated or analysed during this study are included in this published article and its Additional files.

\section{Ethics approval and consent to participate}

Not applicable.

\section{Consent for publication}

Not applicable.

\section{Competing interests}

VK is a Section Editor of BMC Complementary and Alternative Medicine; all the other authors declare that they have no competing interests.

\section{Author details}

'Department of Biochemistry, Faculty of Science, University of Dschang, P.O. Box 67, Dschang, Cameroon. ${ }^{2}$ Department of Biochemistry, Faculty of Science, University of Yaounde I, Yaounde, Cameroon. ${ }^{3}$ Department of Chemistry, Faculty of Science, University of Dschang, Dschang, Cameroon. ${ }^{4}$ Department of Chemistry, Faculty of Science, Eskişehir Technical University, 26470 Eskişehir, Turkey.

\section{Received: 21 March 2019 Accepted: 29 May 2019}

Published online: 06 June 2019

\section{References}

1. Adwan G, Mhanna M. Synergistic effects of plant extracts and antibiotics on staphylococcus aureus strains isolated from clinical specimens. J Sci Res. 2008;3:134-9.

2. Falagas ME, Bliziotis IA. Pandrug-resistant gram-negative bacteria the dawn of the post antibiotic era. Inter J Antimicro Agts. 2007;29:630-6.

3. Amgad AA, Martin RPJ, Ismail MM, Abdelkareem MA, Ahmad MA, Mohamed EH. Antimicrobial activities of seed extracts of mango (MangiferaindicaL.). Adv Microbiol. 2012;2:571-6.

4. Cattoir V. Pompes d'efflux et résistance aux antibiotiques chez les bactéries. Path Biol. 2004:52:607-16.

5. O. Lomovskaya O, Bostian KA. Practical applications and feasibility of efflux pump inhibitors in the clinic-a vision for applied use. Biochem Pharmacol 2006; 71:910-918.

6. Dzotam KJ, Simo Kl, Bitchagno G, Ihami C, Sandjo PL, Tane P, Kuete V. In vitro antibacterial and antibiotic modifying activity of crude extract, fractions and 3', 4', 7- thihydroxyflavone from Myristica fragans Houtt against MDR gram-negative enteric bacteria. BMC Complement Altern Med. 2018;18:15.

7. Kadhim MI, Rana KN, Amaal SA. Antibacterial activity of nutmeg (Myristica fragrans) seed extracts against some pathogenic bacteria. J Al-Nahrain Univ. 2013;16(2):188-92.

8. Djeussi SD, Sandjo PL, Noumedem AJ, Omosa KL, Kuete V. Antibacterial activities of the methanol extracts and compounds from Erythrina sigmoidea against gram-negative multi-drug resistant phenotypes. BMC Complement Altern Med. 2015.

9. Voukeng IK, Kuete V, Dzoyem PJ, Fankam GA, Noumedem AJ, Kuiate RJ, Pages MJ. Antibacterial and antibiotic-potentiation activities of the methanol extract of some Cameroonian spices against gram-negative multidrug resistant phenotypes. BMC Complement Altern Med. 2012;5:299

10. Voukeng IK, Beng VP, Kuete V. Antibacterial activity of six medicinal Cameroonian plants against gram-positive and gram-negative multidrug resistant phenotypes. BMC Complement Altern Med. 2016.

11. Fankam GA, Kuiate RG, Kuete V. Antibacterial and antibiotic resistance modifying activity of the extracts from Allanblackia gabonensis, Combretum mole and Gladiolus quartinianus against gram-negative bacteria including multidrug resistant phenotypes. BMC Complement Altern Med. 2015.

12. Tankeo BS, Damen F, Sandjo PL, Ilhami C, Tane P, Kuete V. Antibacterial activities of the methanol extracts, fractions and compounds from Harungana madagascariensis lam. Ex pair (Hypericaceae). J Ethnopharmacol. 2016;90:100-5

13. Van-Wyk B, Gerick N. People's plants: a guide to useful plants of southern Africa. Pretoria: Briza publications; 2000.
14. Watt J, Breyer-Brandwyk M. The medicinal and poisonous plants of southern and Easthern Africa. 2nd ed. London: Livingstone; 1962

15. Haddad M, Laurens V, Lacaille -Dubois AM. Induction of apoptosis in a leukemia cell line by triterpene saponins from Albizia adianthifolia. Bioorg Med Chem. 2004;12:4725-34

16. Haddad M, Miyamoto T, Laurens V, Lacaille-Dubois AM. Two new biologically active triterpenoidal saponins acylated with salicylic acid from Albizia adianthifolia. J Nat Prods. 2003:66:372-7.

17. Tamokou DJ, Simo JDM, Keilah PL, Tene M, Tane P, Kuiate RJ. Antioxidant and antimicrobial activities of ethyl acetate extract, fractions and compounds from stem bark of Albizia adianthifolia (Mimosoideae). BMC Complement Altern Med. 2012

18. Haddad M, Khan Al, Lacaille-Dubois AM. Two new prosapogenins from Albizia adianthifolia. Pharmazie. 57:705-8.

19. Tchinda CF, Voukeng IK, Beng VP. Kuete $V$ antibacterial activities of the methanol extracts of Albizia adianthifolia, Alchornea laxiflora, Laportea ovalifolia and three other Cameroonian plants against multi-drug resistant gram-negative bacteria. Saudi J Biol Scien. 2016. https://doi.org/10.1016/j. sjbs.2016.01.033.

20. Kuete V, Wabo FG, Ngameni B, Mbaveng TA, Metuno R, Etoa F-X, Lall N. Antimicrobial activity of the methanolic extract, fractions and compounds from the stem bark of Irvingia gabonensis (Ixonanthaceae). J Ethnopharmacol. 2007;114(1):54-60.

21. Eloff JN. A sensitive and quick microplate method to determine the minimal inhibitory concentration of plant extracts for bacteria. Planta Med. 1998;64:711-3

22. Kuete V, Nana F, Ngameni B, T. A. Mbaveng AT, Keumedjio F, Ngadjui BT. Antimicrobial activity of the crude extract, fractions and compounds from stem bark of Ficus ovate (Moraceae). J Ethnopharmacol 2009; 124:556-56.

23. Noumedem J, Mihasan M, Kuiate J, Stefan M, Cojocaru D, Dzoyem J, Kuete $\checkmark$. In vitro antibacterial and antibiotic-potentiation activities of four edible plants against multidrug-resistant gram-negative species. BMC Complement Altern Med. 2013;13:190

24. Seukep JA, Sandjo LP, Ngadjui BT, Kuete V. Antibacterial and antibioticresistance modifying activity of the extracts and compounds from Nauclea pobeguinii against gram-negative multi-drug resistant phenotypes. BMC Complement Altern Med. 2016;16:193. https://doi.org/10.1186/s12906-016$1173-2$

25. Coutinho HD, Vasconcellos A, Freire-Pessoa HL, Gadelha CA, Gadelha TS, Almeida-Filho GG. Natural products from the termite Nasutitermes corniger ower aminoglycoside minimum inhibitory concentrations. Pharmacogn Mag. 2010;6:1-4

26. Braga LC, Leite AA, KGS X, Takahashi JA, Bemquerer MP, Chartone-Souza E, Nascimento AM. Synergic interaction between pomegranate extract and antibiotics against Staphylococcus aureus. Can J Microbiol. 2005:51(7):541-7.

27. Weast RC, Astle JM. CRC handbook of data on organic compounds. Volumes I and II. Boca Raton, FL: CRC Press Inc. s. 1985. 1-927.

28. De-Ekmamkul W, Potduang B. B. Biosynthesis of beta-sitosterol and stigmasterol in Croton sublyratus proceeds via a mixed origin of isoprene units. Phytochemistry. 2003;62(3):389-93.

29. Ramaiarantsoa $H$, Koffi AB, Assi AM, Djakoure LA. Les 3-O- $\beta$-D-glucoside du $\beta$-sitostérol isolés des feuilles de Ravenala madagascariensis. Journal de la Société Ouest-africaine de chine. 2008:26:99-103.

30. Ling-Ling Y, Rong-Tao L, Yuan-Bao A, Wei L, Zhang-Shuang D, Zhong-Mei Z. Protoberberine Isoquinoline alkaloids from Arcangelisia gusanlung. Molecules. 2014:19:13332-41.

31. Dineshkumar B, Analava M, Manjunatha M. Studies on the anti-diabetic and hypolipidemic potentials of mangiferin (Xanthone Glucide) in streptozotocin-induced type 1 and type 2 diabetic model rats. Inter J Adv Pharma Scien. 2010:1:75-85.

32. De Souza RRJ. Mangiferin: Microencapsulation in Pectin/Chitosan Systems, in vitro intestinal metabolism and anticancer activity. Ph.D in Chemistry, University of Cearà, 2012. 1-242.

33. Cowan MM. Plants products as antimicrobial activity. Clin Microbiol Rev. 1999;12(4):564-82.

34. Sharma SK, Singh AP. Antimicrobial investigations on rhizomes of Cyperus rotundus Linn. Pharm Lett. 2011;3(3):427-31.

35. Kuete V, Ngameni B, Tangmouo GJ, Bolla JM, Alibert-Franco S, Ngadjui TB, Pagès JM. Efflux pumps are involved in the defense of gram-negative Bacteria against the natural products Isobavachalcone and Diospyrone. Antimicrob Agents Chemother. 2010;54(5):1749-52. 
36. Mims C, Playfair J, Roitt I, Wakelin D, Williams R. Antimicrobials and chemotherapy. In: Mims, C.A. (Eds.). Med Microbiol Rev 1993; 35:1-34.

37. Mbaveng AT, Kuete V, Mapunya BM, Beng VP, Nkengfack AE, Meyer JJ, Lall N. Evaluation of four Cameroonian medicinal plants for anticancer, antigonorrheal and antireverse transcriptase activities. Envir Toxicol and Pharmacol. 2011;32(2):162-7.

38. Kuete V. Potential of Cameroonian plants and derived products against microbial infections: a review. Planta Med. 2010;76:1-13.

39. Chevalier J, Pagès JM, Eyraud A, Malléa M. Membrane permeability modifications are involved in antibiotic resistance in Klebsiella pneumoniae. Biochem Biophys Res Commun. 2000;274:496-9.

40. Ghisalberti D, Masi M, Pagès JM, Chevalier J. Chloramphenicol and expression of multidrug efflux pump in Enterobacter aerogenes. Biochem Biophys Res Commun. 2005;328:1113-8.

41. Pagès JM, Amiral L. Mechanisms of drug efflux and strategies to combat them: challenging the efflux pump of gram-negative bacteria. Biochem and Biophys Act. 2009;1794:826-33.

42. Lamers RP, Cavallari JF, Burrows LL. The efflux inhibitor phenylalanine arginine beta-naphtylamide permeabilizes the outer membrane of gramnegative bacteria. PLoS One. 2013;8:e60666.

\section{Publisher's Note}

Springer Nature remains neutral with regard to jurisdictional claims in published maps and institutional affiliations.

Ready to submit your research? Choose BMC and benefit from:

- fast, convenient online submission

- thorough peer review by experienced researchers in your field

- rapid publication on acceptance

- support for research data, including large and complex data types

- gold Open Access which fosters wider collaboration and increased citations

- maximum visibility for your research: over $100 \mathrm{M}$ website views per year

At BMC, research is always in progress.

Learn more biomedcentral.com/submissions 